\title{
Notes
}

\section{Constitutional Limits on the Regulation of Laboratory Animal Research}

\author{
Larry T. Garvin
}

Animal rights activists, long unsuccessful, have recently reversed their legislative fortunes. Except for the 1985 amendments $^{1}$ to the federal Animal Welfare Act (AWA), ${ }^{2}$ the successes have occurred at the state and local levels, the scenes of most animal rights lobbying and organization. Most notable are two measures recently enacted in Massachusetts, long a home of anti-vivisectionist ${ }^{3}$ activity. In 1983, Massachusetts became the first, and so far the only, state to ban both the use of in-state pound animals and the importation of out-of-state pound animals for research." In 1987, Cambridge became the first area to ban the $\mathrm{LD}_{50}{ }^{8}$ and Draize

1. Pub. L. No. 99-198, 99 Stat. 1650 (1985) (codified at 7 U.S.C. $\$ \S 2131-57$ (Supp. IV 1986)).

2. Pub. L. No. 89-544, 80 Stat. 350 (1966) (codified as amended at 7 U.S.C. $\$ \S ~ 2131-57$ (1982 \& Supp. IV 1986)).

3. Both anti-vivisectionists and animal rights advocates oppose animal research. Not all antivivisectionists argue that animals have rights; rather, some argue that a purely utilitarian approach leads to a ban on animal experimentation. Sumner, Animal Welfare and Animal Rights, $13 \mathrm{~J}$. MED. \& PHIL. 159 (1988). Some traditional humane societies insist only that research be performed as humanely as possible. Zola, Sechzer, Sieber \& Griffin, Animal Experimentation: Issues for the 1980s, 9 Sci. Teсh. \& Hum. Values 40, 42-43 (1984). However, humane societies have recently become less accommodating to animal research and testing, at times embracing extreme antivivisection positions. Samuels, Transformation of Society's Beliefs Is Goal of Animal Rights Movement, 29 Physiologist 43 (1986).

4. 1983 Mass. Acts 631 (codified in scattered sections of MASS. GEN. LAws ANN. chs. 49A, 140 (West Supp. 1987)).

5. The LD(lethal dose) ${ }_{50}$ test involves giving several groups of animals different doses of the agent tested. The death rates at each dose are then plotted on a graph; by interpolation, it is possible to find the dose at which fifty percent of the animals would die. Trevan, The Error of Determination of Toxicity, 101 Proc. Royal Soc'y London (BIOLOGY) 483 (1927). The test has been criticized because it is highly species-dependent and because the results reflect a complex of biological system failures, thus not giving detailed information on the mechanism by which death occurred. See, e.g., 
tests, often used in product safety evaluation. Since then, other states and local governments have considered such measures; though none have been enacted, many are pending.

The anti-vivisectionists' local successes may prove illusory. Serious constitutional problems should lead to the invalidation of such measures as the Massachusetts and Cambridge statutes. While some local measures may be constitutional, they pose relatively minor threats to research. The permissible national regulations, however, are potentially crippling.

Section I of this Note will place the Massachusetts and Cambridge laws in their historical and legislative context. Section II will argue that laws like the Massachusetts anti-importation law are unconstitutional because they violate the dormant commerce powers of the federal government. Cambridge-type restrictions on animal use, discussed in Section III, are unconstitutional because they are preempted by various federal laws. Moreover, in many states, including Massachusetts, a local ordinance like Cambridge's would violate state preemption law. State and local governments thus cannot regulate many areas of research effectively. Since, however, much of their inability rests on the presence of federal regulations, federal repeal could make much state and local regulation possible. Furthermore, the constitutional impediments addressed here do not bar federal regulation of research. ${ }^{7}$

Office of Technology Assessment, U.S. Cong., Alternatives to Animal Use in Research, Testing, ANd Education 181-83 (1986) [hereinafter Alternatives]. The classical LD $_{50}$ test is not always necessary, as other versions exist that can provide similar results with many fewer animals. However, recent studies have concluded that, in some form, the test is still valuable. See, e.g., Lindgren, Thelestam \& Lindquist, First CFN Symposium: $L D_{50}$ and Possible Alternatives, 52 ACTA Pharmacologica et Toxicologica Supp. II (1983).

6. The Draize test for acute eye irritation requires that the potential irritant be placed on one cye of at least three rabbits. The degree of irritation to the eye is measured over time with reference to standard photos. Draize, Woodard \& Calvery, Methods for the Study of Irritation and Toxicity of Substances Applied Topically to the Shin and Mucous Membranes, 82 J. PHARMacology \& EXPERIMENTAL THERAPEUTICs 377 (1944). The test has been criticized because of the pain and injury to the animals. A. RowAN, OF MICE, MODELS, AND MEN 216-28 (1984). Although tests that do not use live animals are being developed, they are unlikely to supplant the Draize test immediately. AlTERNATIVES, supra note 5 , at 183-84, 188-91.

7. Other issues, such as First Amendment protections, standing, and Fourth Amendment rights, are beyond the scope of this Note. On the relevance of First Amendment protection for scientific research, see, for example, Robertson, The Scientist's Right to Research: A Constitutional Analysis, 51 S. CAL. L. REv. 1203, 1214-40 (1977) (research enjoys protection of the sort recognized in United States v. O'Brien, 391 U.S. 367 (1968), as conduct amounting to speech, due to social value of science recognized in various Court dicta). Contra Francione, Experimentation and the Marketplace Theory of the First Amendment, 136 U. PA. L. REv. 417 (1987); Carter, The Bellman, the Snark, and the Biohazard Debate, 3 YAle L. \& Pol'y REv. 358 (1985). On standing, the leading case is International Primate Protection League v. Institute for Behavioral Research, 799 F.2d 934 (4th Cir. 1986) (animal activists denied standing to compel Secretary of Agriculture to enforce AWA); see also Animal Lovers Volunteer Ass'n v. Weinberger, 765 F.2d 937 (9th Cir. 1985) (no standing under NEPA); Hillsborough County v. Snyder, 516 So. 2d 1105 (Fla. Dist. Ct. App. 1987) (no standing to enjoin pound release). But see Animal Welfare Inst. v. Kreps, 561 F.2d 1002, 1007-10 (D.C. Cir. 1977) (dictum granting activists standing to enforce MMPA); Note, They Asked For Protection and They Got Policy: International Primate's Mutilated Monkeys, 21 AKron L. REv. 97 (1987) (criticizing International Primate); of. Cohen, Congressional Power to Confer Standing: Proposed Amendment to the Animal Welfare Act, Congressional Research Service, No. 87-987 A (Dec. 28, 


\section{Laboratory Animal Regulation in Context}

\section{A. The Historical Dispute}

Anti-cruelty laws were rare until the modern humane movement reached the United States in the 1850 's. ${ }^{8}$ Most states passed general anticruelty laws shortly thereafter. ${ }^{9}$ The anti-vivisection movement started in the 1880 's, soon after the first American physiological laboratories were established. ${ }^{10}$ Despite some early success, including the introduction of bills in the Senate to ban animal research in the District of Columbia, the movement failed to secure any important legislation. ${ }^{11}$ By the 1920's, the movement was moribund.

The rapidly-growing biomedical research community, first roused to action to fight the Congressional bills, ${ }^{12}$ continued to act through the decades that followed. It secured research exceptions to many state anti-cruelty laws ${ }^{13}$ and induced many states and local governments to release pound animals to research laboratories at nominal fees. ${ }^{14}$ By the late 1950's, researchers concentrated on securing federal financial support. Antivivisectionists, though extant, were entirely ineffectual in restricting animal research.

This situation remained until 1965, when Life printed an exposé on dog dealers, revealing that some stole pets and abused their animals. 18 Spurred by the public outrage, Congress passed the Laboratory Animal Welfare Act of $1966,{ }^{16}$ directed towards regulating animal suppliers. Since then, the anti-vivisection movement has received substantial attention. A number of philosophers have sought to provide the movement with

1987) (Congress could grant animal welfare activists standing). Fourth Amendment concerns arise because some states allow humane societies or other animal inspectors to investigate laboratories without warrants. See, e.g., ME. Rev. Stat. ANN. tit. 7, § 391 (West Supp. 1987); Mass. Gen. LAws ANN. ch. 140, $\S 174 D$ (West Supp. 1988). Such searches may violate Fourth Amendment constraints upon illegal searches. Marshall v. Barlow's, Inc., 436 U.S. 307 (1978) (part of Occupational Safety and Health Act which permitted warrantless inspections held unconstitutional); $f$. State v. Osborn, 63 Ohio Misc. 17, 409 N.E.2d 1077 (Montgomery County Ct. 1980) (Fourth Amendment applies to cruelty searches).

8. For a discussion of the origins of the American humane movement, see J. TuRner, ReckonING WITH THE BEAST 45-59 (1980).

9. Before 1850 , seven states and territories had enacted anti-cruelty laws. Seventeen adopted such laws by 1860 , twenty-four by 1870 , and thirty-six by 1880 . All other states enacted them by 1921 . E. Leavitt, Animals and Their Legal Rights 17 (2d ed. 1970).

10. R. Shryock, American Medical Research 59-64 (1947).

11. S. 34, 56th Cong., 1st Sess. (1900); S. 1552, 54th Cong., 1st Sess. (1896); see also J. TuRner, supra note 8, at 94-95, 114-15.

12. J. TURNER, supta note 8 , at 114-15.

13. E.g. Fla. Stat. Ann. $\S 828.02$ (Harrison 1981); Nev. Rev. Stat. $\S 574.200$ (1985). Twenty-two states and the District of Columbia exempt research from animal cruelty statutes. NAtional. Ass'n for Biomedical Research, State Laws Concerning the Use of animals in Research 11 (2d ed. 1987) [hereinafter State LAws].

14. A. Rowan, supra note 6 , at 52 . Challenges by anti-vivisection groups were uniformly unsuccessful. See infra note 73.

15. Silva, Concentration Camps for Dogs, LiFe, Feb. 4, 1966, at 22, 22-29.

16. Pub. L. No. $89-544,80$ Stat. 350 (1966) (codified as amended at 7 U.S.C. $\$ \S ~ 2131-56$ (1982 \& Supp. IV 1986)). 
a theoretical underpinning. ${ }^{17}$ The movement has probably also benefited from increasing public doubt about science. Issues such as genetic engineering and reproductive technologies have moved the public from its earlier support of science to at least a questioning stand. ${ }^{18}$

\section{B. Legislation, Past and Present}

\section{Federal}

Since 1966, the major accomplishments of the anti-vivisectionists at the federal level have been the enactment of amendments to the Animal Welfare Act in 1970, ${ }^{10} 1976,{ }^{20}$ and 1985. ${ }^{21}$ The first two amendments strengthened the provisions concerning animal dealers and added regulations dealing with sport animals. The 1985 amendments addressed laboratories, mandating animal use review committees for federally-funded research institutions ${ }^{22}$ and requiring that animal pain and distress be minimized in the conduct of experiments. ${ }^{23}$ The revised Congressional statement of policy for the AWA makes explicit what has always been implicit in the act: that the purpose of the statute is not to look at the ends of research, but rather to ensure that what the researcher chooses to do is done as humanely as possible. ${ }^{24}$

Several animal protection bills are pending. These include bills to grant animal rights groups third-party standing to enforce the AWA, ${ }^{25}$ to ban the use of pound animals in research conducted with federal funds, ${ }^{26}$ to ban the Draize and $\mathrm{LD}_{50}$ tests, ${ }^{27}$ and to require an exhaustive literature search before any project using live animals could receive federal funds. ${ }^{28}$

17. Among the most prominent philosophers advocating animal rights are Peter Singer and Tom Regan. Singer bases his theory on classical utilitarianism, while Regan derives animal rights from a Kantian perspective. P. Singer, Anmal Liberation (1975); T. Regan, The Case for Animal RIGHTS (1983). They are not without their critics, however, perhaps the most prominent being $R$. G. Frey. R. FREY, INTERESTS AND RIGHTS (1980); see also Cohen, The Case for the Use of Animals in Biomedical Research, 315 NEw ENG. J. MED. 865 (1986).

18. Carter, supra note 7, at 359-61, 386-93.

19. Pub. L. No. 91-579, 84 Stat. 1560 (1970) (codified as amended at 7 U.S.C. $\$ \S 2131-50$ (1982 \& Supp. IV 1986)).

20. Pub. L. No. $94-279,90$ Stat. 417 (1976) (codified as amended at 7 U.S.C. $\$ \S 2131-55$ (1982 \& Supp. IV 1986)).

21. Pub. L. No. 99-198, 99 Stat. 1650 (1985) (codified at 7 U.S.C. $\$ \S 2131-57$ (Supp. IV 1986)).

22. 7 U.S.C. $\$ 2143$ (b) (Supp. IV 1986).

23. 7 U.S.C. $\$ 2143($ a)(3) (Supp. IV 1986).

24. 7 U.S.C. $\S 2131$ (Supp. IV 1986). In the words of the legislative history of the 1970 amendments, "the research scientist . . . holds the key to the laboratory door." H.R. REP. No. 1651, 91st Cong., 2d Sess. 2, reprinted in 1970 U.S. Code Cong. \& ADMin. NEws 5103, 5104.

25. H.R. 1770, 100th Cong., 1st Sess. (1987).

26. S. 1457, 100th Cong., Ist Sess. (1987); H.R. 778, 100th Cong., 1st Sess. (1987).

27. H.R. 1635, 100th Cong., 1st Sess. (1987) (would prohibit use of $\mathrm{LD}_{50}$ test in federal regulations and require that federal regulations specify non-animal tests unless animal tests are more valid).

28. H.R. 1708, 100th Cong., 1st Sess. (1987). 


\section{State and local}

All states have enacted general anti-cruelty legislation. ${ }^{29}$ Twenty-two states and the District of Columbia have carved out explicit statutory exceptions for research. ${ }^{30}$ The rest presumably allow prosecutions of researchers, but only one state has entertained such a suit. In State $v$. $T a u b,{ }^{31}$ a researcher was convicted of mistreating monkeys; the state's highest court reversed, however, finding that researchers could not be prosecuted because the AWA preempted attempts to ban conduct consistent with the Act. $^{32}$ Other states require that research facilities be licensed. $^{33}$ These laws vary; some explicitly track the AWA, ${ }^{34}$ while others provide for different schemes. ${ }^{35}$ None so far has been more restrictive than the AWA.

The most significant type of state and local regulation is pound release laws. By the 1950 's, many states had enacted laws mandating that pound animals be released to researchers, while others gave discretion to local governments. $^{36}$ Since then, especially in the early 1980 's, antivivisectionists have secured the repeal of most mandatory release statutes. $^{37}$ They have converted many permissive states into no-release states ${ }^{38}$ and have also lobbied local governments with some success. ${ }^{39}$

Another line of bills proposes to restrict animal use by banning all animal research ${ }^{40}$ or certain experimental models. ${ }^{41}$ The first type of bill has not been enacted, though it has progressed to committee hearings in the state of Washington. ${ }^{42}$ The second is in place in Cambridge, Massachusetts. There, the city council voted to ban the use of the $\mathrm{LD}_{50}$ and

29. For a recent summary, sec State LAws, supra note 13.

30. Id. at 11.

31. Crim. No. 111848-81 (Md. Dist. Ct. Nov. 23, 1981).

32. Taub v. State, 296 Md. 439, 463 A.2d 819 (1983). For a recent critical discussion, see Comment, Taub v. State: Are State Anti-Cruelty Statutes Sleepirg Giants?, 2 PACE ENVTL. L. REv. 255 (1985); see also New Jersey Soc'y for the Prevention of Cruelty to Animals v. Board of Educ., 91 N.J. Super. 81, 219 A.2d 200 (Law Div. 1966) (barred prosecution of high school researcher under state anti-cruelty statute).

33. State Laws, supra note 13 , at $13-15$.

34. E.g., R.I. GEN. LAwS § 4-19-13 (1987).

35. E.g., Mass. Gen. Laws ANN. ch. 140, $\S 174 D$ (West Supp. 1988).

36. As late as 1973, only three states forbade pound release. Comment, Animal Research and Shelter Animals: An Historical Analysis of the Pound Animal Controversy, 31 ST. Louis U.L.J. 551, 560-61 (1987).

37. Id. at 561-62. Twelve states now prohibit pound release, while only five states and the District of Columbia require it. State Laws, supra note 13, at 9.

38. Comment, supra note 36, at 561-62.

39. Giannelli, The Decline and Fall of Pound Seizure, AnImals' Agenda, July-Aug. 1986, at $10,12$.

40. National Ass'n for Biomedical Research, State Legislative Summary 2 (1987) (Washington bill) [hereinafter Summary].

41. Id. at 3 (Maryland, New Jersey, and Pennsylvania bills on Draize and LD $_{50}$ tests).

42. Getting the Public's Attention, AV, Apr. 1987, at 7. 
Draize tests, both used extensively in product testing and toxicology. ${ }^{43}$ Similar legislation is pending in New Jersey and Pennsylvania.4

\section{The Massachusetts Anti-Importation LaW}

Until 1983, Massachusetts required its pounds to release animals to legitimate research institutions. ${ }^{45}$ Following a long campaign by animal rights groups, the governor signed the most restrictive pound release bill in the nation. ${ }^{48}$ Massachusetts joined eight other states in banning the release of pound animals to laboratories, ${ }^{47}$ but Massachusetts alone forbade the importation of pound animals for research purposes. ${ }^{48}$

Acts banning pound release seem constitutionally valid. Courts have held that animal release is within the police powers of the state, so the state may dispose of pound animals as it wishes. ${ }^{40}$ The Massachusetts anti-importation clause, however, imposes restrictions upon interstate commerce, suggesting that the law may be invalid under the dormant commerce powers of the federal government. so $^{\text {so }}$

Courts invoke the dormant commerce powers to invalidate state or local regulations that impose unnecessarily severe restrictions upon interstate commerce. ${ }^{\text {s1 }}$ The modern test, set out in Pike v. Bruce Church, ${ }^{52}$ relies on

43. Garner, Ban on Lab Testing of Animals Passed, United Press Int'l, May 19, 1987 (NEXIS, Currnt library). The ordinance has not yet taken effect.

44. Summary, supra note 40 , at 3 (Pennsylvania); Cave, The President's Message, AV, Feb. 1988, at 1 (New Jersey).

45. Mass. Gen. Laws AnN. ch. 49A, $\$ \S 2-3$ (West 1968). See also Massachusetts Soc'y for Prevention of Cruelty to Animals v. Commissioner of Pub. Health, 339 Mass. 216, 158 N.E.2d 487 (1959) (rejecting challenge to statute on property rights and improper use of police power grounds).

46. 1983 Mass. Acts 631 (codified in scattered sections of MASs. GEN. LAws ANN. chs. 49A, 140 (West Supp. 1987)).

47. Since then, Delaware, Maryland, and New York have joined this group. STate Laws, supra note 13, at 9. Other states are considering such bans. SumMARY, supra note 40 .

48. 1983 Mass. Acts $631, \S 9$ (codified in Mass. Gen. LAws ANN. ch. 49A, $\S \S 1-10$ note (West Supp. 1987)). Such bills are pending in Oklahoma and Pennsylvania. Summary, supra note 40, at 2; see also National Ass'n for Biomedical Research, ANnual Report 7 (1987) [hereinafter ANNUAL, REPORT].

49. See, e.g., Simpson v. City of Los Angeles, 40 Cal. 2d 271, 253 P.2d 464 (1953); Illinois AntiVivisection Soc'y v. City of Chicago, 289 Ill. App. 391, 7 N.E.2d 379 (1937); Youngblood v. County of Jackson, 28 Mich. App. 361, 184 N.W.2d 290 (1970); Kovar v. City of Cleveland, 60 Ohio L. Abstracts 579, 102 N.E.2d 472 (Ohio Ct. App. 1951); Rapid City v. Tuning, 82 S.D. 442,147 N.W.2d 604 (1967); Regents of the Univ. of Wis. v. Dane County Humane Soc'y, 260 Wis. 486, 51 N.W.2d 56 (1952).

50. This anti-importation clause may also violate the takings clause of the Fifth Amendment, either because it destroys a Massachusetts research laboratory or animal supplier or because it bankrupts an out-of-state supplier. This seems improbable, however, because out-of-state dealers operate in a fairly open market and are unlikely to suffer more than transient losses. In-state laboratories have other, albeit more expensive, sources of supply. See infra notes 102-105 and accompanying text. Although in-state suppliers may suffer substantially, police power regulations seldom constitute takings, especially when they concern the removal of a state-granted privilege. See infra note 114.

51. See infra notes 84-109 and accompanying text. Courts and academics have long debated the bases of the dormant commerce doctrine. Some cases and commentators contend that the doctrine is designed to promote free trade and economic integration. See, e.g., Hughes v. Oklahoma, 441 U.S. 322, 325-26 (1979); Collins, Economic Union as a Constitutional Value, 63 N.Y.U. L. REv. 43 (1988); Dowling, Interstate Commerce and State Power, 27 VA. L. REv. 1, 19-28 (1940). Other commentators argue that the dormant commerce clause exists to protect out-of-state firms from the 
interest balancing. If a state or local statute regulates intrastate and interstate commerce evenly in order to promote a legitimate state interest, with only incidental effects upon interstate commerce, then it will be held valid unless the burden imposed upon such commerce greatly exceeds the putative local benefit. ${ }^{\mathrm{ss}}$ The relevant factor here is whether the local interest could be promoted with less effect upon interstate commerce. ${ }^{\text {st }}$

\section{A. Overt Discrimination Against Interstate Commerce}

A law applying harsher standards to out-of-state firms than to those instate is suspect under the underlying concepts of free trade and non-citizen representation, and the Court will scrutinize it closely. ${ }^{55}$ The Massachusetts law does not discriminate overtly against interstate commerce. The law affects Massachusetts animal dealers just as it does those out-ofstate. $^{\text {s8 }}$ As the law does not restrict imports of kennel-bred animals for research, it appears not to discriminate in favor of local kennels. ${ }^{67}$ Therefore, the strict test does not apply here. Since the law is facially neutral, the Pike interest balancing test should be applied. ${ }^{88}$

\section{B. Legitimate State Interests}

A legitimate state interest must promote a material advance in an area in which the legislature is institutionally capable of acting. ${ }^{59}$ The legislation need not in fact further such interests, though the legislators must

workings of political bodies in which they are unrepresented, e.g., Eule, Laying the Dormant Commerce Clause to Rest, 91 YALE L.J. 425, 429-35 (1982), or to prevent discrimination against suspect classifications, e.g., Regan, The Supreme Court and State Protectionism: Making Sense of the Dormant Commerce Clause, 84 Mich. L. REv. 1091, 1094-95 (1986). This argument is endorsed by some recent case law. See Minnesota v. Clover Leaf Creamery, 449 U.S. 456, 473 n.17 (1981) (state ban on sale of milk in plastic containers upheld, in part because in-state container manufacturers could represent the interests of those out-of-state).

52. 397 U.S. 137, 142 (1970).

53. Id.; see also Arkansas Elec. Coop. v. Arkansas Pub. Serv. Comm'n, 461 U.S. 375, 395 (1983) (upholding statute that exerts only incidental effects on out-of-state pricing and has substantial and justifiable effects on those in-state). This test has been criticized recently by some commentators who would restrict dormant commerce clause investigations to overt discrimination. See, e.g., Regan, supra note 51.

54. Pike, 397 U.S. at 142.

55. City of Philadelphia v. New Jersey, 437 U.S. 617, 624 (1978) ("[w]here simple economic protectionism is effected by state legislation, a virtually per se rule of invalidity has been erected."); accord Maine v. Taylor, 106 S. Ct. 2440, 2448 (1986) (burden of persuasion shifts to state when statute is facially discriminatory).

56. Mass. Gen. Laws ANN. ch. 49A, $\S \S 1-10$ note (West Supp. 1988).

57. Animals are generally purchased from the most convenient source, which is usually the researchers' local pound for dogs and cats. But it is customary to order smaller animals from national dealers, which generally involves interstate shipment. Thus, laboratory animal purchasers, though perhaps preferring local suppliers, are by no means averse to long-distance animal purchases.

58. If a law advances no legitimate state interest, which happens only rarely, the law falls. See Welton v. Missouri, 91 U.S. 275 (1876) (striking state law licensing only peddlers selling out-of-state merchandise).

59. See, e.g., Great Atl. \& Pac. Tea Co. v. Cottrell, 424 U.S. 366, 371 (1976) (states have broad power to legislate in matters of local concern). 
have been able to believe that it would. ${ }^{60}$ The Massachusetts law advances three legitimate interests. ${ }^{.1}$

First, the bill may have been intended to eliminate the use of pets in research on the grounds that pets, due to their special association with humans, are ill-adapted to, or inappropriate for, laboratory research. ${ }^{\mathbf{6 2}}$ Courts have long held anti-cruelty laws within the police power of the state. ${ }^{63} \mathrm{~A}$ pet protection law may be read to prevent cruelty to a special subclass of animals. Second, Massachusetts may have an interest in protecting the moral beliefs of those people who find research on former pets ethically revolting. Protecting morals also has long stood within a state's general police powers and consequently qualifies as a legitimate state interest. ${ }^{64}$ Finally, the bill may have been intended to reduce animal research, the goal of the New England Anti-Vivisection Society. ${ }^{65}$ Attempts to regulate research already fall under routine anti-cruelty laws. ${ }^{86}$ Thus, Massachusetts has advanced legitimate state interests through its antiimportation law.

60. See Kassel v. Consolidated Freightways, 450 U.S. 662, 680 (1981) (Brennan, J., concurring).

61. Other suggested interests are invalid. Massachusetts might have wanted to prevent diseased animals from entering the state. Quarantines have long been held permissible. See, e.g., Mintz v. Baldwin, 289 U.S. 346 (1933) (upholding state law requiring that all imported cattle and their herds have been tested free of Bang's disease). But this law is too narrow for that purpose, as pound animals not for sale to researchers may be imported without any special regard to health. Furthermore, Massachusetts law requires that potentially diseased animals be inspected. MASS. GEN. Laws ANN. ch. $140, \S 138 \mathrm{~A}$ (West Supp, 1988). Underinclusive legislation is not inherently void; the test is whether the legislature "could rationally have decided" to legislate incompletely in order that its ends be furthered. Cloverleaf, 449 U.S. at 466 . However, underinclusive statutes are suspect in commerce clause litigation because they may be employed to strike against a protected group, whether the protection stems from free trade or the Fourteenth Amendment. Kassel, 450 U.S. at 662, 675-78 (invalidated state ban on long tractor-trailers in part because state excepted most intrastate vehicles). There is also no evidence that this rationale was considered seriously by the legislature; though actual legislative intent is not necessary, it carries weight. South Carolina State Highway Dep't v. Barnwell Bros., 303 U.S. 177, 192-93 (1938) (legislative intent generally sets bounds on possible purpose for commerce clause analysis). Disease prevention is thus an inherently implausible rationale for the law.

The state may also believe, as did Congress when it passed the first Animal Welfare Act, that pet owners should not be robbed of their runaway dogs and cats. S. REP. No. 1281, 89th Cong., 2d. Sess., reprinted in 1966 U.S. CoDE Cong. \& ADMIN. NEws 2635, 2652. This is a legitimate state interest for the state in which the animal runs away, but not in any other. The Court has consistently struck down statutes of one state that attempt to regulate the affairs of another. See, e.g., Brown-Forman Distillers v. New York Liquor Auth., 476 U.S. 573 (1986) (striking down law requiring that out-ofstate price reductions by in-state wholesalers be approved by in-state board); Public Utils. Comm'n v. Attleboro Steam \& Elec. Co., 273 U.S. 83 (1927) (voiding attempt to regulate price charged by instate utility to out-of-state customers).

62. A. RowaN, supra note 6 , at 152 (citing proponents who stated that former pets are unacceptable for research because the laboratory is "foreign and threatening").

63. Haviland v. Butz, 543 F.2d 169 (D.C. Cir. 1976) (upholding AWA); Thiele v. City \& County of Denver, 135 Colo. 442, 312 P.2d 786 (1957) (state law); Commonwealth v. Turner, 145 Mass. 296, 14 N.E. 130 (1887) (same).

64. See, e.g., Day-Brite Lighting v. Missouri, 342 U.S. 421, 424 (1952) (police power "extends ... to all the great public needs").

65. Cohen, Pound Animals for Research and Education, 27 PHysiologist 190, 191 (1984).

66. See supra note 13 and accompanying text. Cf. Comment, supra note 32 (state animal laws often allow charges to be made against researchers); Comment, Creating a Cause of Action Against Abusive Animal Research, 134 U. PA. L. Rev. 399 (1986) (suggesting animal welfare ordinances and nuisance law be implemented through more liberal use of standing doctrine). 


\section{Impediments to Interstate Commerce}

Once a court finds a legitimate state interest, the court must weigh the extent to which the legislation advances the interest against the impairment it works upon interstate commerce. ${ }^{67}$ The burden on interstate commerce is significant. Some seventy percent of the dogs used in animal research come from pounds. ${ }^{68}$ Researchers favor pound animals because of the price; while pound dogs cost from five to fifteen dollars if unconditioned and $\$ 75$ to $\$ 140$ if conditioned, purpose-bred dogs cost at least $\$ 275$ each, with some recent estimates running from $\$ 750$ to $\$ 1200 .^{69} \mathrm{Al}$ though no precise figures are available, it has been estimated that Massachusetts laboratories use roughly 5,000 dogs each year. ${ }^{70}$ Thus, the actual annual cost of the anti-importation provision is from $\$ 1,000,000$ to $\$ 4,000,000 .{ }^{.1}$ The Supreme Court uses the cost that a statute places upon those affected by it as a means of determining whether the statute substantially burdens interstate commerce. ${ }^{22}$ It has found significant burdens in cases involving smaller sums; ${ }^{73}$ although it is hard to compare the relative effect in those cases with the effects here, anecdotal evidence suggests that some Massachusetts researchers have been severely restricted by the rise in costs. ${ }^{74}$

\section{Balancing Under Pike}

If the state interest were weighed against the impairment on interstate commerce, the Massachusetts law would be invalidated. Comparing financial impediments to moral and ethical benefits is difficult. The Massachusetts law only marginally reduces animal research, as it does not restrict the use of kennel-bred animals or pets donated directly to the laboratories. In light of the substantial burdens the law imposes upon interstate com-

67. Pike, 397 U.S. at 142.

68. See Ringler \& Peter, Dogs and Cats, in Laboratory Animal Medicine (J. Fox, B. Cohen \& F. Loew eds. 1984).

69. $\Lambda$. Rowan, supra note 6, at 159 (\$275) (1984 estimate); Cohen, supra note 65, at 190 (\$750) (1984 estimate); Metz, From the Labs to the Legislatures, STUdent LAw., Oct. 1986 at $15(\$ 1,200)$ (1986 estimate). Conditioned animals are pound animals that have been treated for any diseases they may have contracted before or during their time as strays. A. RowAN, supra note 6, at 158-59.

70. A. Rowan, supra note 6 , at 152 .

71. A recent estimate places the national cost of a pound animal ban at $\$ 90,000,000$. Smith \& Hendee, Animals in Research, 259 J. A.M.A. 2007, 2007 (1988); see also A. Rowan, supra note 6, at 152 (early 1980's estimate that Massachusetts act would cost $\$ 1,000,000$ ).

If importation were allowed, the laboratories that once bought pound animals would go to the next cheapest source of supply, out-of-state dealers who purchased pound animals and either sold them untreated or conditioned them first. Consequently, the loss falls entirely upon interstate commerce.

72. Raymond Motor Transp., Inc. v. Rice, 434 U.S. 429, 445 (1978).

73. See, e.g., id. at 439 n.14 (shipping cost increases of $\$ 2,000,000$ and $\$ 165,000$ ); Bibb v. Navajo Freight Lines, 359 U.S. 520, 525 (1959) (appellees' total cost due to regulation approximately $\$ 50,000)$.

74. White, The Facts About Animal Research, ReAder's Digest, Mar. 1988, at 127, 129 (cardiovascular research at Harvard and Massachusetts General Hospital curtailed). 
merce, this state interest cannot itself support the law. ${ }^{75}$ The moral interest makes this a close question. Although there is no directly comparable authority in dormant commerce clause jurisprudence, the Court has looked rather skeptically at assertions of intangible benefits in standing and equal protection cases. ${ }^{76}$ Although it is impossible to predict how a court will employ a balancing test with certainty, the relatively weak state interests in banning pound animal imports, when combined with the substantial burden upon interstate commerce, make it likely that the Massachusetts anti-importation act would be overturned.

\section{The Gambridge Commercial Research Restrictions}

In 1987, Cambridge became the first city to enact an ordinance limiting animal experimentation, banning two widely-used and widely-criticized toxicological tests, the $\mathrm{LD}_{50}$ and Draize tests. ${ }^{77}$ Cambridge specifically excepted non-commercial research from its proscription, ${ }^{78}$ but, in spite of its narrow scope, such an ordinance is preempted by federal law and, in many states (including Massachusetts), by state law as well. ${ }^{79}$

\section{A. Federal Preemption}

The Supreme Court has fashioned three tests to determine whether a state or local law is preempted. First, a local law is void if Congress has displayed an intent to occupy the field of the conflict. ${ }^{80}$ Second, where it is impossible to comply with both a federal statute and a local law, the local law yields. ${ }^{81}$ Finally, local laws are invalid where they frustrate the intent

75. See, e.g., Raymond, 434 U.S. 429; Bibb, 359 U.S. 520 (laws stricken that minimally advanced state interest while placing significant burdens on interstate commerce).

76. See, e.g., San Antonio School Dist. v. Rodriguez, 411 U.S. 1 (1973) (education not fundamental right under equal protection analysis); International Primate Protection League v. Institute for Behavioral Research, 799 F.2d 934 (4th Cir. 1986), cert. denied, 107 S. Ct. 1624 (1987) (animal rights group seeking to enforce AWA denied standing because it lacked tangible interest in law's enforcement); $c f$. Breard v. Alexandria, 341 U.S. 622 (1951) (upholding on privacy grounds statute banning door-to-door sales except where homeowner consents, despite interference with interstate commerce). The interests of pound animals do not rise to constitutional levels. See Miles v. City Council, 710 F.2d 1542, 1544 n.5 (11th Cir. 1983) (cat not person and hence lacks Bill of Rights protections). But of. Forum, Just Like Us?, HARPER's, Aug. 1988, at 43, 51-52 (advocating constitutional amendment granting animals rights).

77. Garner, supra note 43; for descriptions of the tests, see supra notes 5-6.

78. Lettvin, The Need for Animal Lab Tests, 30 PHysiologist 49 (1987).

79. Moreover, it could effect a taking compensable under the Fifth Amendment. Since Pennsylvania Coal Co. v. Mahon, 260 U.S. 393 (1922), it has been accepted that a regulation could constitute a taking. See, e.g., Ruckelshaus v. Monsanto Co., 467 U.S. 986 (1984) (release of trade secret a taking). However, the Court is reluctant to impede a state's police power, and consequently seldom grants compensation for a regulatory taking. Keystone Bituminous Coal Ass'n v. DeBenedictis, 480 U.S. 470 (1987). It is unlikely that a testing laboratory could demonstrate that it was all but destroyed by this ordinance, as these tests do not comprise all of the business of a testing firm. Consequently, while it is possible that a firm would undergo such a cataclysm that the courts could find a regulatory taking, it is very improbable. See supra note 50.

80. Rice v. Santa Fe Elevator, Inc., 331 U.S. 218 (1947); see also Schneidewind v. ANR Pipeline Co., 108 S. Ct. 1145,1150 (1988).

81. Florida Lime \& Avocado Growers, Inc. v. Paul, 373 U.S. 132 (1963); see also Schneidewind, 108 S. Ct. at $1150-51$. 
of Congress, even where Congress has displayed no preemptive intent. ${ }^{82} \mathrm{~A}$ law will be preempted if it fails any one of these tests. Ordinances such as the one enacted by Cambridge can survive the first test, but will fail the second and perhaps the third.

\section{The Occupied Field Test}

In Rice v. Santa $\mathrm{Fe}$ Elevator, the Court held that, where Congress displays an intent to occupy a field, any state law within that field is preempted. ${ }^{83}$ This "occupied field" test has been reaffirmed repeatedly. ${ }^{84}$ The text and legislative history of the AWA do not reveal any preemptive intent. Section 15(b) of the AWA provides that "the Secretary [of Agriculture] is authorized to cooperate with the officials of the various States or political subdivisions thereof in effectuating the purposes of this Act and of any State, local, or municipal legislation or ordinance on the same subject." ${ }^{85}$ This provision on its face disavows preemption.

It is possible that Congress intended to preserve state laws existing when the AWA was passed, none of which extended appreciably beyond the scope of the Act. Section 15(b) would then only permit laws consistent with the AWA. Other federal regulatory laws operate in this manner. ${ }^{86}$ However, the legislative history of the AWA suggests that the clause should be read to accommodate local measures. In an exchange on the floor of the House, the sponsor of the bill, referring to possible state bans upon the purchase of pound dogs for research, stated that "[the bill] will not add to the authority to buy anything that is prohibited by State law." ${ }^{87}$ Thus, Rice preemption does not void the Cambridge ordinance.

\section{The Conflicting Regulations Test}

The second test for preemption, expressed most clearly in Florida Lime \& Avocado Growers, Inc. v. Paul, states that preemption occurs if it is impossible to obey both state and federal law. ${ }^{88}$ Where both the state and

82. Hines v. Davidowitz, 312 U.S. 52 (1941); see also Schneidewind, 108 S. Ct. at 1151.

83. Rice, 331 U.S. at 230.

84. See, e.g., Silkwood v. Kerr-McGee Corp., 464 U.S. 238 (1984) (Price-Anderson Act does not occupy field of tort remedies for nuclear accidents); Sperry v. Florida ex rel. Florida Bar, 373 U.S. 379, 395-96 (1963) (Patent Act occupies field of patent agent licensure).

85. Pub. L. No. $89-544, \S 15,80$ Stat. 350 (1966) (codified as amended at 7 U.S.C. $\S 2145$ (b) (1982)). See also Winkler v. Colorado Dep't of Health, 193 Colo. 170, 175-76, 564 P.2d 107, 111 (1977) (state regulation imposing quarantine on animals from states with less restrictive licensing laws not preempted by AWA).

86. See, e.g., Ray v. Atlantic Richfield, 435 U.S. 151 (1978) (Ports and Waterways Safety Act permits states to regulate tanker safety design only within confines of Federal statutes and regulations).

87. 112 Cong. Rec. 9210 (1966) (statement of Rep. Poage).

88. 373 U.S. at 142-43 (California statute mandating higher minimum oil content in avocados than federal standard not preempted). 
federal laws establish minimum standards, it is possible to obey both. ${ }^{89}$ If the AWA sets minima, a more restrictive state or local regulation does not flatly contradict the standards but rather supplements them. Indeed, Florida Lime and the cases since distinguish between federal minimum and maximum standards. The former, generally devised for consumer protection or safety, imply no preemptive intent absent specific language; Congress is presumed only to have set up a foundation upon which otherwise valid state and local laws may build. ${ }^{90}$ Local governments, however, may not exceed federal maxima. ${ }^{91}$ At times, Congress seeks to protect an industry or group by devising safe zones in which local regulation is unconstitutional. ${ }^{92}$ In practice, the Court tends to accept local regulations made in exercise of the police power unless they burden interstate commerce severely or run afoul of the frustrated purposes test discussed below. ${ }^{93}$ Under the Florida Lime test, the AWA does not impede the Cambridgetype ordinance.

But other federal statutes and regulations do. ${ }^{94}$ The Court has consistently held that federal laws mandating positive action may not be frustrated by local bans. ${ }^{95}$ Several federal statutes and regulations require that $\mathrm{LD}_{50}$ and Draize tests be performed by various chemical, pesticide, and pharmaceutical manufacturers. The Federal Hazardous Substances Labeling Act, ${ }^{96}$ for example, defines hazardous substances in relation to animal test results, including the Draize and $\mathrm{LD}_{50}$ tests. ${ }^{97}$ Failure to per-

\section{Id.}

90. Id. at 147-48; California Fed. Sav. \& Loan Ass'n v. Guerra, 107 S. Ct. 683 (1987) (California law requiring pregnancy leave benefits above federal level not preempted).

91. See, e.g., Jones v. Rath Packing, 430 U.S. 519, 540-43 (1977) (more stringent state weights and measures law preempted by Federal Meat Inspection Act).

92. Congress can, for example, preempt state regulations by proscription. Puerto Rico Dep't of Consumer Affairs v. Isla Petroleum Corp., 108 S. Ct. 1350, 1353 (1988) (Puerto Rico gasoline regulations not preempted by Congressional repeal of comprehensive regulatory scheme); Arkansas Elec. Coop. v. Arkansas Pub. Serv. Comm'n, 461 U.S. 375, 384 (1983)("federal decision to forgo regulation in a given area may ... . have as much pre-emptive force as a decision to regulate") (emphasis in original).

93. See, e.g., Hillsborough County v. Automated Medical Laboratories, 471 U.S. 707, 713-18 (1985) (FDA regulations do not preempt local blood donation ordinance); Maryland v. Louisiana, 451 U.S. 725, 746-47 (1981) (general presumption that Congress did not intend to preempt state law, applied to state petroleum tax).

94. Regulations, as well as statutes, may preempt local legislation. Hillsborough, 471 U.S. at 713.

95. See, e.g., Lawrence County v. Lead-Deadwood School Dist., 469 U.S. 256 (1985) (federal statute requiring that federal payments to school districts be used freely preempts state law dictating means of expenditure); Capital Cities Cable, Inc. v. Crisp, 467 U.S. 691 (1984) (state law banning alcoholic beverage advertisements on out-of-state signals carried by cable preempted by FCC regulations requiring that such signals be carried in full); Farmers Educ. \& Coop. Union v. WDAY, 360 U.S. 525, 535 (1959) (federal statutory duty to broadcast replies to political messages preempts state law banning them).

96. Pub. L. No. $86-613,74$ Stat. 372 (1960) (codified as amended at 15 U.S.C. $\$ \S 1261-76$ (1982)).

97. 15 U.S.C. $\S 1261(\mathrm{~h})$-(k) (1982). Equivalent human data take precedence. 15 U.S.C. $\S$ 1261(h)(2) (1982); see also H.R. REP. No. 1861, 86th Cong., 2d Sess., reprinted in 1960 U.S. ConE CoNG. \& ADMIN. NEws 2833, 2838. It seems unlikely, however, that anecdotal evidence, the only kind generally available from humans, could substitute for animal data. Occasional unwitting poisonings and industrial accidents do not replace systematic data in any but the most unusual cases. AL- 
form these tests makes it criminal to introduce the substance into interstate commerce. ${ }^{98}$ Thus, the Cambridge ordinance makes it impossible for a manufacturer to comply with federal law if he wishes to operate outside his own state. Given the rather expansive interpretation of the commerce clause long accepted by the Court, ${ }^{90}$ it seems likely that most businesses would be caught between federal and local law here.

Other federal statutes impose similar obligations on manufacturers. The Toxic Substances Control Act ${ }^{100}$ allows the EPA Administrator to direct that manufacturers test chemicals potentially hazardous to either humans or the environment in order to assess the extent of the danger and thus to promulgate regulations for their handling. ${ }^{101}$ The statute lists animal tests as one of the options which the Administrator may choose in setting up a roster of acceptable tests. ${ }^{102}$ The regulations in fact mandate that $L D_{50}$ and Draize tests be performed when the EPA requires data on acute toxicity and primary eye irritation not otherwise available. ${ }^{103}$ Similarly, the Federal Environmental Pesticide Control Act of $1972,{ }^{104}$ which requires that manufacturers register pesticides intended for more than laboratory use with the EPA Administrator and provide such data as the Administrator may desire, ${ }^{103}$ mandates $\mathrm{LD}_{50}$ and Draize tests for all chemical and most biological pesticides. ${ }^{108}$ In a different field, the Virus-Serum-Toxin Act of $1913^{107}$ prohibits the sale of viruses, sera, and antitoxins except when manufactured and tested under guidelines established by the Secretary of Agriculture. ${ }^{108}$ These guidelines use $\mathrm{LD}_{50}$ data to define the safety and purity tests. ${ }^{109}$ Consequently, these agents cannot now be manufactured without recourse to a test banned by Cambridge. Other statutes and regulations have similar effects. ${ }^{110}$ Thus, a large body of positive federal

TERNATIVES, supra note 5 , at $26-29$.

98. 15 U.S.C. $\S 1263$ (1982).

99. See, e.g., Hodel v. Virginia Surface Mining \& Reclamation Ass'n, 452 U.S. 264, 276 (1981) (federal reclamation statute within commerce powers if there is any rational basis for Congress to have believed that regulated activity affected interstate commerce); Katzenbach v. McClung, 379 U.S. 294 (1964) (upholding federal regulation of business that, though not itself substantially in interstate commerce, is part of class of businesses that is).

100. Pub. L. No. 94-469, 90 Stat. 2003 (1976) (codified as amended at 15 U.S.C. $\$ \S 2601-29$ (1982)).

101. 15 U.S.C. $\$ 2603$ (a) (1982).

102. 15 U.S.C. $\S 2603(\mathrm{~b})(2)(\mathrm{A})(1982)$.

103. 40 C.F.R. $\S \S 798.1100-.1175\left(L_{50}\right), 798.4500$ (Draize) (1987). In neither case are any alternatives listed.

104. Pub. L. No. 92-516, 86 Stat. 973 (1972) (codified as amended at 7 U.S.C. $\S 136(1982)$ ).

105. 7 U.S.C. $\S 136 \mathrm{a}(\mathrm{c})(2)(\mathrm{A})(1982)$.

106. 40 C.F.R. $\$ 158.135, .145$ (1987).

107. Ch. 145,37 Stat. 828 (1913) (codified as amended at 21 U.S.C. $\S \S 151-58$ (1982)).

108. 21 U.S.C. $\S 151$ (1982).

109. E.g., 9 C.F.R. $\S 113.104$ (1988).

110. For example, the Hazardous Materials Transportation Act, Pub. L. No. 93-633, tit. I, 88 Stat. 2156 (1975) (codified as amended at 49 U.S.C. $\$ \S 1801-12$ (1982)) requires that toxicity studies be done for materials shipped in interstate commerce for which the extent of toxicity is not yet known. Toxicity is defined in terms of an $\mathrm{LD}_{50}$ test. Other statutes enable regulations that require testing for health safety without specifying protocols. See, e.g., Federal Trade Commission Act, ch. 311, 38 Stat. 
law requires what Cambridge forbids, thereby preempting Cambridge's ordinance. ${ }^{111}$

It could be argued that Cambridge's ban exerts a de minimis effect upon the requirements of the federal laws described above. This would be true if the ordinance in fact prevented very little testing. ${ }^{12}$ A drug manufacturer based in Cambridge could farm out its toxicity testing, though probably at some inconvenience or expense. A commercial testing firm could likewise reallocate its resources. This would, however, make conformity with federal law a burden, which is generally per se grounds for preemption. ${ }^{113}$ Furthermore, Florida Lime analysis does not allow an exemption for de minimis preemption. ${ }^{114}$

\section{The "Frustrated Purpose" Test}

In Hines v. Davidowitz, ${ }^{116}$ the Supreme Court held that state laws inconsistent with the aims and purposes of federal law are preempted, even when Congress has not expressed an intent to occupy the field. ${ }^{116}$ It is not easy to divine the aims of the federal laws on animal research. However, the federal government promotes experimentation and, to a degree, animal testing. The laws and regulations discussed above speak to the latter,;12 as to the former, the National Institutes of Health estimate that the federal government spent over seven billion dollars on health research and devel-

717 (1914) (codified as amended at 15 U.S.C. $\$ \S 41-58$ (1982)); Clean Air Act, Pub. L. No. 88-206, 77 Stat. 392 (1963) (codified as amended at 42 U.S.C. $\$ \S 7401-642$ (1982)); Federal Food, Drug and Cosmetic Act of 1938, ch. 675, 52 Stat. 1040 (1938) (codified as amended at 21 U.S.C. \$§ 301-92 (1982)). The FDA has developed guidelines for testing that include extensive animal tests; these guidelines, while acknowledging that $L_{50}$ tests have value, do not require them. 53 Fed. Reg. 39,650 (1988).

111. Moreover, failure to comply with federal safety standards has been held to constitute negligence per se under state law. See, e.g., Griffin v. United States, 351 F. Supp. 10, 34 (E.D. Pa. 1972), affd in part and rev'd in part on other grounds, 500 F.2d 1059 (3d Gir. 1974) (Sabin oral polio vaccine); see also Restatement (SECOND) Of TORTS $\$ 288(B)(1)$ (1965) (failure to meet governmental safety standard is negligence).

112. In fact, one account of the Cambridge ordinance noted that the relevant tests might not even be performed in Cambridge. "Council Backs Ban on Certain Animal Research, But Extent of Use Unclear," Associated Press, May 19, 1987 (NEXIS library, Currnt file).

113. See Nash v. Florida Indus. Comm'n, 389 U.S. 235 (1967) (invalidating state unemployment compensation law because it denied benefits to those seeking to exercise federal statutory rights); $c f$. California Fed. Sav. \& Loan Ass'n v. Guerra, 107 S. Ct. 683 (1987) (some state-imposed burden acceptable when furthering equal protection clause rights).

114. The test set forth in Florida Lime does not mention any weighing of interests. Instead, it considers only whether it is possible to obey both federal and state law. Florida Lime, 373 U.S. at 141-43, 146-52.

115. 312 U.S. 52 (1941) (invalidating state law regulating alien movements).

116. Several scholars have criticized this line of cases for its potential expansiveness. See, e.g., Engdahl, Conflicting Jurisdiction of Federal, State, and Local Authorities; The Federal Preemption Doctrine, 31 Rocky MTN. MrN. L. INST. 1-1 (1985); Rothschild, A Proposed "Tonic" with Florida Lime to Celebrate our New Federalism: How to Deal with the "Headache" of Preemption, $38 \mathrm{U}$. Míami L. Rev. 829 (1984).

117. See supra notes $94-111$ and accompanying text. American industry spent roughly $\$ 650$ million on toxicological testing in 1985, mainly to fulfill federal requirements. ALTERNATIves, supra note 5 , at 251 . 
opment in $1986 .^{118}$ Many federal departments and agencies both perform research and sponsor outside research: literally hundreds of statutory references permit or require federal units to do animal research. ${ }^{118}$ In the AWA amendments of 1985 , Congress stated that "the use of animals is instrumental in certain research and education for advancing knowledge of cures and treatment for diseases and injuries which afflict both humans and animals."120 A state or local ban on research, as proposed in several cities and states, ${ }^{121}$ frustrates a general federal intent to promote research. Hence, proposals to ban all animal research would be preempted under Hines as well as under Florida Lime.

Whether this would apply to the Cambridge ordinance is a more difficult question. Hines is usually invoked when the states interfere with peculiarly national powers. ${ }^{122}$ Here, local governments would regulate research using their health and welfare powers, which the Court has repeatedly held are quintessentially local. ${ }^{123}$ This does not mean that local interests are so immediate that they trump more general federal interests; rather, where an area potentially under conflict is within traditional local powers, the Court has favored co-regulation. ${ }^{124}$ It is unclear whether Cambridge's ban would withstand this type of preemption analysis.

It would be difficult to make the Cambridge ordinance both effective and constitutional. The ordinance would have to exclude all federallyrequired research and testing to get by the hurdles described above. It would also have to exclude all research and testing by the federal government. The Court recently reaffirmed that "the activities of federal installations are shielded by the Supremacy Clause from direct state regulation unless Congress provides 'clear and unambiguous' authorization for such regulation."125 The AWA does not explicitly authorize the regulation of

118. U.S. Def't. of Health \& Human Services, Nat'l Institutes of Health, NIH DATA BoOK 2 (1987). The states spent somewhat less than $\$ 1$ billion, while industry spent approximately $\$ 5.6$ billion and private non-profits $\$ 625$ million. $I d$.

119. One recent survey found seven departments and five independent agencies with active animal research programs. ALTERNATIVES, supta note 5, at 44-46.

120. Pub. L. No. 99-198, $\S 1751$, 99 Stat. 1354 (1985) (codified at 7 U.S.C. $\S 2131$ (Supp. IV 1986)).

121. Trull \& Kalikow, Animal Rights Movement: A Threat to Biomedical Research?, 2 CANCER INVESTIGATION 479, 480 (1984); ANNUAL REPORT, supta note 48, at 7-9.

122. Hines concerned the power to regulate immigration and nationalization. See also Xerox Corp. v. County of Harris, 459 U.S. 145 (1982) (state tax on goods held in custom warehouse preempted where Congress intended to set up duty-free system for imported products awaiting export).

123. See, e.g., Silkwood v. Kerr-McGee Corp., 464 U.S. 238 (1984); Grayned v. City of Rockford, 408 U.S. 104 (1972) (noise control); Florida Lime, 373 U.S. at 132.

124. See, e.g., California Coastal Comm'n v. Granite Rock, 107 S. Ct. 1419 (1987) (state licensing requirement for mining validly applied to mining on federal lands by federal permit holders); Pacific Gas \& Elec. Co. v. State Energy Comm'n, 461 U.S. 190 (1983) (California moratorium on certification of nuclear waste disposal plants not preempted by federal nuclear regulatory law). However, these cases refer to limits or heightened requirements rather than to bans. In Granite Rock, for example, the Court noted that the state had not actually banned mining; if it had, the Court said, the case might be different. $107 \mathrm{~S}$. Ct. at 1429.

125. Goodyear Atomic Corp. v. Miller, 108 S. Ct. 1704, 1709 (1988) (quoting EPA v. State Water Resources Control Bd., 426 U.S. 200, 211 (1976)). 
federal facilities, though it contemplates a degree of state regulation. ${ }^{128}$ The statutes requiring animal tests also do not explicitly authorize state contravention. Moreover, federal contractors, including grant recipients, ${ }^{127}$ also appear immune from a Cambridge-type ban. ${ }^{128}$ As a result, to withstand challenge, any ordinance would have to exclude virtually all researchers who would seek to perform Draize or $\mathrm{LD}_{50}$ tests.

\section{B. State Preemption}

The Cambridge-type ordinance does not escape invalidation if it survives federal preemption analysis. Virtually all local ordinances are potentially invalidated by state law as well. Though localities stand in much the same relationship to states as states do to the federal government, the analogy is imperfect and state and federal preemption jurisprudence differ.

The basic difference comes from the relative subordination of localities to states. Local governments exist as creatures of the state and thus are subject to whatever degree of control the legislature wishes to impose. ${ }^{129}$ State constitutional and statutory provisions and common-law standards do, however, provide some limits on the ability of state legislatures to preempt local actions. ${ }^{130}$

The requirements differ in home rule and non-home-rule states. ${ }^{131}$ Home rule refers to local governments that derive their powers from either constitutional or statutory provisions that create areas in which local law prevails over state law if not in direct conflict with it or in which local law supersedes state law entirely. Washington's Constitution, like that of several other states, grants local governments the power to enact "such local police, sanitary and other regulations as are not in conflict with general law."132 Illinois's Constitution, in contrast, allows home rule units to

126. 7 U.S.C. $§ 2145$ (b) (1982).

127. See Gabig, Federal Research Grants: Who Owns the Intellectual Property?, 16 PuB. ConT. L.J. 187, 189 (1986).

128. See, e.g., Boyle v. United Technologies Corp., 108 S. Ct. 2510 (1988) (state tort law preempted by federal common law immunizing federal contractors); Leslie Miller, Inc. v. Arkansas, 352 U.S. 187 (1956) (state law requiring contractors to secure state permits unconstitutionally applied to federal contractor, which is immune from regulations that would counter goals of federal government); United States v. Town of Windsor, 765 F.2d 16 (2d Cir. 1985) (state building code preempted for contractor for federal facility).

129. See, e.g., Williams v. Mayor of Baltimore, 289 U.S. 36, 40 (1933) (municipal corporation "has no privileges or immunities under the federal constitution which it may invoke in opposition to the will of its creator"); City of Trenton v. New Jersey, 262 U.S. 182, 187 (1923) (municipalities have no inherent right of self-government beyond state legislative control). The Court has since qualified this for voting rights, the sole exception. Avery v. Midland County, 390 U.S. 474 (1968) (oneman, one-vote principle applies to local government elections); Gomillion v. Lightfoot, 364 U.S. 339 (1960) (state revision of municipal boundaries limited by Fifteenth Amendment).

130. For a thorough survey of the field, see 1 C. SAndS \& M. Libonati, Local Government LAw §§ 3.09-.20, 4.07-.12 (1981 \& Supp. 1987).

131. Thirty-seven states have home rule provisions in their constitutions. 1 C. ANTIEAv, MuNrcipal. Corporation Law $\$ 3.00$ (1988).

132. Wash. Const. art. XI, $\$ 11$. 
exercise "any power ... pertaining to its government . . . including but not limited to, the power to regulate for the protection of the public health, safety, morals, and welfare; to license; to tax; and to incur debt." ${ }^{133}$ Home rule has initiative and protective functions; the former allow the locality to act, while the latter secure release from preemptive state legislation. ${ }^{134}$ In non-home-rule states, local governments only legislate as far as the state legislature allows; their enactments are at all times subject to preemption, constrained only by the state common law that may have developed.

The protective functions are relevant here. Under Washington's Constitution, state preemption requires only a conflict; ${ }^{138}$ under Illinois law, however, the legislature must explicitly preempt a field to shut out municipal action. ${ }^{138}$ Preemption doctrine is even more complicated in non-homerule states, for which the courts have devised elaborate sets of preemption criteria. In People v. Llewellyn, ${ }^{137}$ for example, the Michigan Supreme Court held that the legislature preempts local laws if the legislature expressly reserves powers, implies preemption in the legislative history, devises a pervasive regulatory scheme, ${ }^{\mathbf{1 3 8}}$ or regulates in a field that by its nature demands exclusive state regulation. ${ }^{139}$ In contrast, Kentucky adopted a less generous test from California case law: state law preempts local law (a) if the former fully covers the field, thus making local law superfluous, (b) if it partially covers the field, but a paramount state concern will not tolerate additional local action, or (c) if the adverse effect of the local ordinance on transient citizens of the state outweighs the possible benefit to the municipality. ${ }^{140}$ In non-home-rule states, local statutes generally fail when they affect any function outside the municipality in which the state has a police power or other governmental interest. ${ }^{141}$ In these

133. ILL. CoNST. art. VII, $\S 6$. Many states have chosen legislative grants of home rule, giving municipalities the state's police powers subject to specific legislative action. See, e.g., IND. CODE ANN. $\$ \$ 36-1-3-1$ to -9 (Burns 1981 \& Supp. 1988).

134. Sandalow, The Limits of Municipal Power Under Home Rule: A Role for the Courts, 48 MiNN. L. REv. 643 (1964).

135. See, e.g., General Tel. Co. v. City of Bothell, 105 Wash. 2d 579, 716 P.2d 879 (1986) (state utility regulations preempt conflicting local ordinance).

136. See, e.g., Peters v. City of Springfield, 57 Ill. 2d 142, 311 N.E.2d 107 (1974) (city's retirement age ordinance not preempted by state municipal code). However, municipalities may not regulate in areas traditionally of statewide concern. Ampersand, Inc. v. Finley, 61 Ill. 2d 537, 338 N.E.2d 15 (1975). See generally Michael \& Norton, Home Rule in Illinois: A Functional Analysis, 1978 U. IL.L. L.F. 559.

137. 401 Mich. 314, 257 N.W.2d 902 (1977).

138. Development of a regulatory scheme would only be one factor favoring preemption. 401 Mfich. at 323-24, 257 N.W.2d at 905. Cf. Rice v. Santa Fe Elevator, 331 U.S. 218 (1947) (federal pervasive regulatory scheme itself preempts state and local law). See also supra notes 83-87 and accompanying text for a discussion of federal preemption doctrine on this point.

139. Llewellyn, 401 Mich. at 324-26, 257 N.W.2d at 905-06.

140. Commonwealth $v$. Do, Inc., 674 S.W.2d 519, 521 (Ky. 1984). The test was taken from In re Hubbard, 62 Cal. 2d 119, 396 P.2d 809, 41 Cal. Rptr. 393 (1964).

141. See Feiler, Conflict Between State and Local Enactments-The Doctrine of Implied Preemption, 2 URB. LAw. 398, 404-06 (1970); Note, Conflicts Between State Statutes and Municipal Ordinances. 72 HARV. L. REv. 737, 744-45 (1959). 
and most other home rule cases, however, the courts balance state and local interests. ${ }^{142}$

Given the wide range of both preemption doctrines and state laws, a Cambridge-type ordinance would be valid in some states but not others. The ordinance, however, is automatically suspect because it invokes the health and welfare powers of government, which most states find are matters of general interest and hence not within the unique scope of local government. ${ }^{143}$ Courts have held that animal regulation is not exclusively a local affair. ${ }^{144}$ Hence, even the home rule states that grant substantial exclusive powers to the locality may preempt a Cambridge-like ordinance.

State preemption, then, could occur in several ways. If the state's regulations expressly or implicitly authorize $\mathrm{LD}_{50}$ or Draize testing, local ordinances banning them would be preempted. ${ }^{145} \mathrm{~A}$ general animal testing regulatory scheme might also preempt a Cambridge-type ordinance, in the same manner that a Berkeley ordinance banning electroconvulsive therapy was recently held preempted because state regulation of such therapy indicated the state's interest in its continued practice. ${ }^{146}$ Many states require $\mathrm{LD}_{50}$ or Draize testing in their environmental or safety regulations. ${ }^{147}$ As with similar federal legislation under Florida Lime, the local ordinance would be preempted. ${ }^{148}$

The Kentucky preemption rules suggest a Hines-like approach to preemption. ${ }^{148}$ Kentucky balances local and state interests, with local laws presumed valid if they operate within traditional municipal powers. ${ }^{250}$

142. See, e.g., Northern Cal. Psychiatric Soc'y v. City of Berkeley, 178 Cal. App. 3d 90, 223 Cal. Rptr. 609 (1986) (balancing municipal interest in health and welfare against state interest in uniform medical regulations).

143. 2 E. McQuillin, Municipal Corporations $\$ 4.99$ (3d ed. 1979 \& Supp. 1987 ); 0. Reynolds, Local Government LAw 107-10 (1982) (summarizing current law).

144. See, e.g., Simpson v. City of Los Angeles, 40 Cal. 2d 271, 253 P.2d 464 (1953) (upholding pound relcase laws); County of Peoria v. Capitelli, 144 Ill. App. 3d 14, 494 N.E.2d 155 (1986) (same).

145. See, e.g., Do, 674 S.W.2d at 521; City of Shreveport v. Curry, 357 So. 2d 1078, 1080 (La. 1978) (municipal ordinance preempted when it forbids what state authorizes).

146. Psychiatric Soc'y, 178 Cal. App. 3d at 90, 223 Cal. Rptr. at 609.

147. Many states explicitly require the $\mathrm{LD}_{50}$ or Draize tests in their regulations. See, e.g., CAL. ADMIN. CODE tit. $22, \$ \S 66696,66720$ (1987) (defines hazardous waste by $\mathrm{LD}_{50}$ values); 5 Colo. CODE REgs. \$ 3.1.8(3)(b)(v) (1987) (maximum concentrations of toxic substances in sewage mixing zones defined by $\mathrm{LC}_{50}$ values); IOwA ADMIN. CODE r. 30-10.21 (1986) (pesticide toxicity defined by $\mathrm{LD}_{50}$ values); MICH. ADMIN. CODE rr. 408.11605(5), 408.11607(2) (1979) (defining toxicity for occupational hazards by $L_{50}$ values); MINN. R. 7045.0129(1)(B), .0131(6) (1987) (defines hazardous waste by $\mathrm{LD}_{50}$ values); OHIO ADMIN. CODE $\S 3745-51-11(\mathrm{~A})(2)$ (1986) (defines hazardous waste by $L_{50}$ values); OR. ADMIN. R. 333-16-005(5) to (8) (1980) (defines hazardous substances by $L_{50}$ and Draize results); S.C. Cone REGs. 5-390(d) to (g) (1976) (same). Alternatively, states simply adopt federal regulations that require $\mathrm{LD}_{50}$ or Draize tests. See, e.g., GA. CoMp. R. \& REGS. r. 391 3-11-.07 (1987) (adopting federal hazardous waste definitions); ILL. ADMIN. CoDE tit. 77, \$ 850.20 (1985) (adopting federal hazardous substances definitions); KAN. ADMIN. REGs. 28-31-3(a) (1986) (adopting federal hazardous waste regulations); CODE ME. R. ch. 800, $\$ 4(A)$ (1987) (adopting federal Clean Water Act regulations).

148. See supra notes $88-114$ and accompanying text.

149. See supra notes 115-24 and accompanying text.

150. See Andersen, Resolving State/Local Governmental Conflict-A Tale of Three Cities, 18 
Consequently, a state's desire to sell safe commodities could preempt testing bans where the tests banned are very significant and the ban raises significantly the cost or difficulty in performing them. Such balancing tests depend greatly on the facts of each case. State courts, however, often find local law preempted. For example, courts have granted state policies encouraging group homes supremacy over local zoning ordinances forbidding them. ${ }^{151}$ Similarly, state licenses given to toxic waste dumps override local ordinances forbidding them. ${ }^{162}$

In summary, a Cambridge-type ordinance would probably be preempted in many states, including Massachusetts, which requires $L D_{50}$ and Draize tests in its hazardous substances regulations. ${ }^{163}$ Though the Supreme Judicial Court of Massachusetts has adopted a very strict preemption standard, it includes Florida Lime-like factors which would lead to preemption. ${ }^{154}$ Since other states have even more expansive preemption doctrines, state preemption law is an additional obstacle for the proponents of a Cambridge-type ordinance. ${ }^{285}$

\section{GoNCLUSION}

The two state and local measures that have attempted to restrict laboratory animal research are unconstitutional. Furthermore, the legal principles that render these invalid would also render invalid more extreme laws of the same types. This suggests that anti-vivisectionists may have chosen their focus badly. If the federal government were to ban required animal use, the preemption problems of the Cambridge ordinance would fall. Likewise, though Massachusetts may not bar the importation of pound animals for research purposes, the federal government may condition grants on their non-use, which would effectively ban them. ${ }^{158}$ This

URB. L. ANN. 129, 150-51 (1980) (suggesting use of presumptions to help explain and resolve law).

151. See, e.g., Region 10 Client Management, Inc. v. Town of Hampstead, 120 N.H. 885, 424 A.2d 207 (1980); Volunteers of America Care Facilities v. Village of Brown Deer, 97 Wis. 2d 619, 294 N.W.2d 44 (1980). See generally Hopperton, A State Legislative Strategy for Ending Exclusionary Zoning of Community Homes, 19 URB. L. ANN. 47 (1980).

152. Township of Cascade v. Cascade Resources Recovery, Inc., 118 Mich. App. 580, 325 N.W.2d 500 (1982); Southern Ocean Landfill, Inc. v. Mayor of Ocean, 64 N.J. 190, 314 A.2d 65 (1974); of. California Coastal Comm'n v. Granite Rock Co., 107 S. Ct. 1419 (1987) (federal mining permit to mine on federal land does not preempt state law requiring independent state permit); Pacific Gas \& Elec. Co. v. State Energy Comm'n, 461 U.S. 190 (1983) (state moratorium on nuclear waste dumping not preempted by federal regulations). See supra notes 115-24 and accompanying text.

153. MASS. Code Regs. tit. 105, $\$ \$ 650.004$ to .006 (1987).

154. Barlow v. Town of Wareham, 401 Mass. 408, 517 N.E.2d 146 (1988) (local laws not preempted unless state legislative purpose cannot be achieved if they coexist with state laws).

155. In addition, state contractors may have immunity from local regulation similar to that enjoyed by federal contractors. E \& E Hauling, Inc. v. Forest Preserve Dist., 821 F.2d 433 (7th Cir. 1987) (local regulation placing higher requirements on state contractor than those mandated by state is preempted); see also supra notes $125-28$ and accompanying text.

156. Although the government cannot condition grants on abridgement of constitutional rights or privileges, a requirement that research grant recipients not use pound animals is not an "unconstitutional condition," as the right to perform research lacks independent constitutional grounds. Compare Sherbert v. Verner, 374 U.S. 398 (1963) (invalidating requirement that unemployment benefit recipi- 
applies to more radical measures as well. For example, the federal government need not fund animal research beyond its current contractual commitments. ${ }^{157}$ It could ban the shipment of any laboratory animal in interstate commerce. ${ }^{188}$ Either measure would devastate animal research.

While such measures are constitutionally acceptable, they may be undesirable. This Note has outlined the broad issues on which the legal battles must turn and has demonstrated that current approaches face grave problems. Paradoxically, animal rights advocates have been directing their efforts of late precisely where they can secure the least real success, local pound release bans aside. The extent to which the federal umbrella shields animal research must be recognized. But, as Professor Stephen Carter has observed, even legal victories for researchers may prove Pyrrhic if the populace responds with more severe strictures. ${ }^{159} \mathrm{~A}$ dramatic example of the possibility is the battle over the patentability of higher organisms. ${ }^{160}$ Anti-vivisectionists may have mobilized well after all; though the local and state laws may prove either unconstitutional or relatively harmless to researchers, they may help bring the public behind more damaging federal measures. ${ }^{161}$ In the long run, researchers cannot rely upon constitutional arguments to protect their present rights to perform humane animal research.

ent be willing to accept work on her Sabbath as unconstitutional condition premising grant on violation of free exercise clause) with Steward Machine Co. v. Davis, 301 U.S. 548 (1937) (upholding ninety percent unemployment tax credit to employers in states that adopted unemployment plans meeting federal standards as, in effect, conditional grant not involving constitutional right); see also Rosenthal, Conditional Federal Spending and the Gonstitution, 39 STAN. L. REv. 1103 (1987) (discussing unconstitutional condition doctrine).

157. Cf. Maher v. Roe, 432 U.S. 464 (1977) (right to abortion does not entail right to federal funding).

158. Cf. United States v. Darby, 312 U.S. 100 (1941) (federal government may prohibit shipment of goods in interstate commerce when manufactured in violation of Fair Labor Standards Act).

159. Carter, supra note 7, at 379-86.

160. Wallis, Should Animals Be Patented?, Tne, May 4, 1987, at 110.

161. A recent poll shows that $81 \%$ of Americans think it necessary to use animals in some applied medical research, while $72 \%$ do for basic medical research and $61 \%$ for allergy testing. However, $76 \%$ think that animals have rights, though only $46 \%$ of those think that the use of animals in research violates those rights. $72 \%$ believe that pound release is acceptable. Although only $55 \%$ approve of the use of dogs in experiments, $60 \%$ of those who disapprove would approve if dogs were the only animals suitable for life-saving experiments. Kilman, Are Laboratory Animals Treated Humanely?, Associated Press, Oct. 28, 1985 (NEXIS, Currnt library). The results are at times contradictory; nevertheless, one may conclude that at present there is substantial support for research in this country. But see Williams, Americans Are Nuts Over Pets, But Maybe That's Not So Nutty, N.Y. Times, Aug. 17, 1988 , at 19, col. 1 (Congress receives more mail on animal use in research than any other subject; mail runs $99 \%$ against animal use). 